Click www.researchjournal.co.in/online/subdetail.html to purchase.

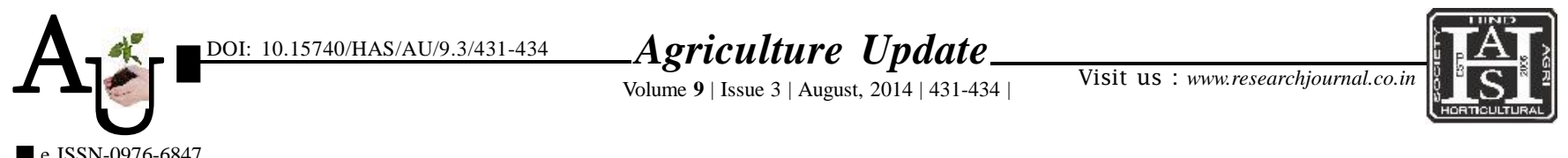

Research Article

\title{
Relationship between personal variable of the respondents with adoption level of redgram growers
}

\author{
KIRAN KUMAR JADHAV AND S.G. ASKI
}

Article Chronicle: $\quad$ Summary : The research study was conducted in Bijapur district of Karnataka during the year 2013 with Received :

24.06.2014;

Revised :

12.07.2014;

Accepted :

22.07.2014

sample size of 140 respondents. The findings revealed that, independent variables viz., education, mass media participation, extension participation and achievement motivation exhibited positive and significant relationship at one per cent level and extension contact at five per cent level, whereas age, family size, land holding, annual income and risk orientation exhibited non-significant relationship with adoption level of trained farmers. With respect to untrained respondents the independent variables like, education and extension participation exhibited positive and significant relationship at one per cent level and variables like mass media participation and extension contact exhibited positive and significant relationship at five per cent level, whereas family size, land holding, annual income, risk orientation and achievement motivation exhibited positive and non-significant relationship with adoption level. There was positive and significant relationship at one per cent level between knowledge and adoption level of the trained respondents and in case of untrained respondents, there was positive and significant relationship at five per cent level between knowledge and adoption level.

\section{KEY Words:}

How to cite this article : Jadhav, Kiran Kumar and Aski, S.G. (2014). Relationship between personal variable of the

Extension contact, Extension participation, Mass media participation, Risk orientation, Achievement motivation.

\section{S.G. ASKI}

Department of Agricultural Extension Education, Agriculture College, BIJAPUR (KARNATAKA) INDIA Email: askisubhash@ gmail.com

See end of the article for authors' affiliations 